\title{
Adaptation Strategies followed by the Rice Growers to Mitigate the Impact of Climate Change
}

\author{
P. Suganthkumar ${ }^{1} \& H$. Philip $^{2}$
}

\begin{abstract}
The study was conducted in Orathanadu block of Thanjavur district in Tamil Nadu. Proportionate random sampling was employed to select the sample. It was observed that the variables viz., educational status and fatalism showed positive significant correlation at one per cent level of probability whereas awareness on climate change showed negative correlation. Variables like annual income, extension agency contact and awareness on crop insurance showed negative correlation at five per cent level of probability
\end{abstract}

Keywords : Climate change; Adaptation strategy; Livelihood; Food security; Tamil Nadu

\section{INTRODUCTION}

Climate change is any significant long-term change in the expected patterns of average weather of a region (or the whole Earth) over a significant period of time, that may have influence on adequate stock and flow of food and cash to meet the basic needs (livelihood), the ability of an individual to have all time physical and economical access to sufficient and safe food for a healthy life (food security). Agriculture has been adversely affected by climate change. To sustain their livelihood in this changing climate, farmers are taking many alternative adaptive measures to manage its ill effects.

According to UNDP (2005), adaptation is a process by which strategies to moderate, cope with and take advantage of the consequences of climatic events are enhanced, developed and implemented. Conversely, the greater the degree of preparatory adaptation, the less may be the impacts associated with any given degree of climate change. Adaptation at farm-level involves two stages: perceiving the change in climate, and deciding whether to adapt or not, or which adaptation strategy to choose (Maddison, 2007). In this study, the farmers had taken many adaptive measures with respect to crop diversification, cropping intensity, farm operations, soil and water conservation measures and animal husbandry. The correlation and regression tests were applied to ascertain the relationship of profile of the farmers with the adaptation strategy and the results are discussed.

1. PG Scholar, Department of Agricultural Extension and Rural Sociology, TNAU, Coimbatore - 641003 and

2. Director of Extension Education (DEE), Tamil Nadu Agricultural University, Coimbatore-641 003

Received : 23-04-2018; Accepted : 02-06-2018 
Adaptation Stratagies followed by the Rice Growers to Mitigate the Impact of Climate Change

\section{METHODOLOGY}

The selected study area was Thanjavur district of Tamil Nadu. The study area was selected purposively for this study. Among 14 agricultural blocks in Thanjavur district, Orathanadu block was selected for study as it had highest area of rice cultivation and more number of farmers. Based on the number of farmers in the villages, the villages namely, Thirumangalakkottai (East), Poyyundarkottai, Vadakkurnorth and Vellur from Orathanadu block were selected to represent the rice growers of the district.

Proportionate random sampling was used to select 120 respondents from the selected four villages. Fifteen independent variables were selected to study the profile of the farmers. The scores obtained for each item by an individual respondent were summed up to obtain total score for adaptive behaviour towards climate variability. The correlation and regression tests were applied to ascertain the relationship of independent variable with the adaptation strategy followed by the farmers to ensure livelihood and food security.

\section{FINDINGS AND DISCUSSION}

Profile of the respondents

The profile of the respondents were analyzed using percentage analysis and it was found that the majority $(60.00 \%)$ of the respondents in the study area belonged to old age category with middle and high school level of education. And majority (72.50 \%) of the farmers was found to have medium sized family of four to six members with majority $(65.00 \%)$ of the respondents having medium level of annual income. Majority of the farmers in the study area had diversified their crop (68.30\%) and enterprise (80.00\%). They cultivated other crops like pulses, oilseeds etc. The respondents were found to have high level of awareness on climate change and crop insurance with high level of decision making behavior.

Table 1.

Relationship of Profile of Farmers with Adaptation to climate change

\begin{tabular}{|c|l|c|c|c|c|}
\hline $\begin{array}{c}\text { Variable } \\
\text { No. }\end{array}$ & \multicolumn{1}{|c|}{ Variables } & $\begin{array}{c}\text { Correlation } \\
\text { coefficient }\end{array}$ & $\begin{array}{c}\text { Regression } \\
\text { coefficient }\end{array}$ & $\begin{array}{c}\text { Standard } \\
\text { error }\end{array}$ & ' $\mathrm{t}$ ' \\
\hline & Constant & & 57.188 & 4.939 & 11.579 \\
\hline X1 & Age & 0.110 & 0.862 & 0.423 & $2.038^{*}$ \\
\hline X2 & Educational status & $0.705^{*}$ & 1.098 & 0.159 & $6.901^{* *}$ \\
\hline X3 & Annual Income & $-0.231^{*}$ & 0.001 & 0.123 & 0.010 \\
\hline X4 & Family Size & -0.069 & 0.420 & 0.322 & 1.304 \\
\hline X5 & Occupational Status & -0.008 & 0.220 & 0.408 & 0.539 \\
\hline X6 & Farming experience & 0.118 & 0.259 & 0.325 & 0.796 \\
\hline X7 & Crop diversification & 0.167 & 0.295 & 0.131 & $2.254^{*}$ \\
\hline X8 & Enterprise diversification & $0.522^{* *}$ & 0.394 & 0.169 & $2.330^{*}$ \\
\hline
\end{tabular}




\begin{tabular}{|c|l|c|c|c|c|}
\hline $\begin{array}{c}\text { Variable } \\
\text { No. }\end{array}$ & \multicolumn{1}{|c|}{ Variables } & $\begin{array}{c}\text { Correlation } \\
\text { coefficient }\end{array}$ & $\begin{array}{c}\text { Regression } \\
\text { coefficient }\end{array}$ & $\begin{array}{c}\text { Standard } \\
\text { error }\end{array}$ & ' $\mathrm{t}^{\prime}$ \\
\hline $\mathrm{X} 9$ & Fatalism & -0.168 & -0.164 & 0.127 & -1.292 \\
\hline $\mathrm{X} 10$ & Extension agency contact & $-0.202^{*}$ & -0.012 & 0.127 & -0.097 \\
\hline $\mathrm{X} 11$ & $\begin{array}{l}\text { Exposure to weather } \\
\text { advisory }\end{array}$ & $-0.207^{*}$ & -0.113 & 0.133 & -0.853 \\
\hline $\mathrm{X} 12$ & $\begin{array}{l}\text { Utility of weather based } \\
\text { agro advisory services }\end{array}$ & -0.086 & -0.161 & 0.215 & -0.748 \\
\hline $\mathrm{X} 13$ & $\begin{array}{l}\text { Awareness on climate } \\
\text { change }\end{array}$ & $-0.267^{* *}$ & -0.312 & 0.212 & -1.475 \\
\hline $\mathrm{X} 14$ & $\begin{array}{l}\text { Awareness on crop } \\
\text { insurance }\end{array}$ & $-0.227^{*}$ & -0.646 & 0.393 & -1.647 \\
\hline $\mathrm{X} 15$ & $\begin{array}{l}\text { Decision making on } \\
\text { climate change }\end{array}$ & 0.159 & 0.070 & 0.192 & 0.362 \\
\hline
\end{tabular}

* Significance at 0.05 level

$$
\mathrm{R}^{2}=0.605
$$

** Significance at 0.01 level

\section{Relationship of Profile Characteristics of Farmers with Adaptation to climate change}

From Table 1, it is observed that the variables viz., educational status and fatalism showed positive significant correlation at one per cent level of probability whereas awareness on climate change showed negative correlation at one per cent level. Variables like annual income, extension agency contact and awareness on crop insurance showed negative correlation at five per cent level of probability.

Multiple regression analysis was taken up to find out the contribution of independent variable with adaptation to climate change. The $R^{2}$ value was 0.60 . The $R^{2}$ value has shown that all the variables contributed 60.50 per cent variation in the adaptation level of the respondents. The regression coefficient values were found to be positive and significant.
Therefore the equation was worked out.

$\mathrm{Y} 1=57.188+0.862\left(\mathrm{X}_{1}\right)+1.908\left(\mathrm{X}_{2}\right)+0.001$ $\left(X_{3}\right)+0.420\left(X_{4}\right)+0.220\left(X_{5}\right)+0.259\left(X_{6}\right)+$ $0.295\left(X_{7}\right)+0.394\left(X_{8}\right)-0.164\left(X_{9}\right)-0.012$ $\left(X_{10}\right)-0.113\left(X_{11}\right)-0.161\left(X_{12}\right)-0.312\left(X_{13}\right)-$ $0.646\left(X_{14}\right)+0.070\left(X_{15}\right)$.

The results indicated that the variables viz., age, crop diversification and enterprise diversification showed positive significant contribution at five per cent level of probability. Educational status alone showed positive contribution at one percent level of probability. Results revealed that one unit increase in the following independent variables viz., age $\left(X_{1}\right)$, educational status $\left(X_{2}\right)$, crop diversification $\left(X_{7}\right)$ and enterprise diversification $\left(X_{8}\right)$ would increase the adaptation to climate change by $0.862,1.098,0.295,0.394$ units respectively. 
As the farmers grow older, their experience in farming get increased which may increase their exposure on farming. Increase in exposure to farming may make the farmers aware of the measures to cope up with the adverse situation of climate change. This might be the reason for positive contribution of age towards adaptation strategy.

The farmers were well educated and their education status was primary, secondary level to collegiate level. It is an accepted fact that educated farmers always understood the changes in the climate and it influences farming very quickly than illiterate farmers and were able to take alternate measures to cope with the situation. The study is in accordance with the findings of Dhaka et al., (2010) who revealed that education had increased the level of adaptation of improved technologies to mitigate the climate change.

\section{CONCLUSION}

Diversification of enterprises and crops helped the farmers to mitigate the ill effects of climate change. Hence, higher the diversification of crops and enterprise, higher will be the adaptation. The results are in line with findings of Rubina (2014) who revealed that enterprise diversification increases the level of adoption of technologies to climate change.

\section{REFERENCES}

Dhaka, B.L., Chayal, K., \& Poonia, M.K. (2010). Analysis of farmers perception and adaptation strategies to climate change. Libyan Agriculture Research Center Journal International, 1(6), 388-390.

Maddison, D. (2007). The perception and adaptation to climate change in Africa. CEEPA. Centre for Environmental Economics and Policy in Africa. Discussion Paper No. 10, University of Pretoria , Pretoria, South Africa

Rubina, S. M. (2014). Impact of climate change on adaptation and mitigation strategies of Ponnaniyar and Kalingarayan basin farmers - A Gender analysis. Unpublished Master's Thesis, AC\&RI, TNAU, Coimbatore.

Sivaraj, P., \& Philip, H. (2014). Climate change impact on paddy farming in Erode and Tiruchirappalli District of Tamil Nadu. Journal of Extension Education 27(4)

UNDP. (2005). Adaptation policy frameworks for climate change. Developing Strategies, Policies and Measures. UNDP, New York. 